\title{
Transcriptome Analysis of Zygotic Induction During Conjugative Transfer of Plasmid RP4
}

OPEN ACCESS

Edited by:

Chin-Yi Chen,

United States Department

of Agriculture, United States

Reviewed by:

Mark Glover,

University of Alberta, Canada

Christopher Morton Thomas,

University of Birmingham,

United Kingdom

Jun Lu,

University of Alberta, Canada, in collaboration with reviewer $M G$

*Correspondence:

Masatoshi Miyakoshi mmiyakoshi@md.tsukuba.ac.jp Masataka Tsuda mtsuda@tohoku.ac.jp

Specialty section:

This article was submitted to

Evolutionary and Genomic Microbiology,

a section of the journal

Frontiers in Microbiology

Received: 13 March 2020

Accepted: 05 May 2020

Published: 18 June 2020

Citation:

Miyakoshi M, Ohtsubo Y,

Nagata Y and Tsuda M (2020)

Transcriptome Analysis of Zygotic Induction During Conjugative Transfer of Plasmid RP4.

Front. Microbiol. 11:1125. doi: 10.3389/fmicb.2020.01125

\author{
Masatoshi Miyakoshi,2*, Yoshiyuki Ohtsubo' ${ }^{1}$ Yuji Nagata' ${ }^{1}$ and Masataka Tsuda ${ }^{1 *}$ \\ 'Department of Molecular and Chemical Life Sciences, Graduate School of Life Sciences, Tohoku University, Sendai, Japan, \\ ${ }^{2}$ Division of Biomedical Science, Faculty of Medicine, University of Tsukuba, Tsukuba, Japan
}

Conjugative transfer of bacterial plasmid is one of the major mechanisms of horizontal gene transfer, which is mediated by direct contact between donor and recipient cells. Gene expression of a conjugative plasmid is tightly regulated mostly by plasmidencoded transcriptional regulators, but it remains obscure how differently plasmid genes are expressed in each cell during the conjugation event. Here, we report a comprehensive analysis of gene expression during conjugative transfer of plasmid RP4, which is transferred between isogenic strains of Pseudomonas putida KT2440 at very high frequency. To discriminate the expression changes in the donor and recipient cells, we took advantage of conjugation in the presence of rifampicin (Rif). Within 10 min of mating, we successfully detected transient transcription of plasmid genes in the resultant transconjugant cells. This phenomenon known as zygotic induction is likely attributed to derepression of multiple RP4-encoded repressors. Interestingly, we also observed that the traJIH operon encoding relaxase and its auxiliary proteins were upregulated specifically in the donor cells. Identification of the $5^{\prime}$ end of the zygotically induced traJ mRNA confirmed that the transcription start site of traJ was located 24-nt upstream of the nick site in the origin of transfer (oriT) as previously reported. Since the traJ promoter is encoded on the region to be transferred first, the relaxase may be expressed in the donor cell after regeneration of the oriT-flanking region, which in itself is likely to displace the autogenous repressors around oriT. This study provides new insights into the regulation of plasmid transfer processes.

Keywords: transcriptome, conjugative transfer, relaxosome, RP4, zygotic induction

\section{INTRODUCTION}

Plasmids are extra-chromosomal genetic elements that replicate autonomously by plasmidencoded elements in cooperation with the host cell chromosome and are vertically inherited by cell division through active partitioning, multimer resolution, and post-segregational killing mechanisms. They can also be propagated horizontally by conjugative transfer through direct contact between donor and recipient cells (Thomas and Nielsen, 2005). In Gram-negative bacteria, plasmids are replicated commonly by the theta replication system during vegetative growth and also by the rolling-circle replication (RCR) system during conjugative transfer (Willetts and Wilkins, 1984; Waters and Guiney, 1993; Lanka and Wilkins, 1995; Llosa et al., 2002; de la Cruz et al., 2010). The origins of the two modes of plasmid replication are designated as oriV and oriT, respectively. 
Self-transmissible plasmid is equipped with a conjugative transfer system mainly composed of a DNA processing machinery for transfer and replication (Dtr) and a type IV secretion system (T4SS) for mating pair formation (Mpf), the latter of which is embedded in membranes of a donor cell and penetrates into a recipient cell (Lawley et al., 2004; Cabezón et al., 2015; Waksman, 2019). A conjugative plasmid prepares for transfer through an assembly of protein complexes called relaxosome at the origin of transfer (oriT) region and then cleavage of the double-stranded plasmid DNA by relaxase, a class of the HUH endonuclease superfamily (Chandler et al., 2013). The relaxase specifically cleaves the nick site (nic) in oriT using a tyrosine residue in its catalytic transesterase domain, which covalently binds with the $5^{\prime}$-end phosphate of the transfer strand. The relaxase is recruited to the T4SS by a coupling protein, and both the relaxase and the single-stranded DNA (ssDNA) are transported unidirectionally with a $5^{\prime}$ to $3^{\prime}$ polarity from the donor to the recipient through the same T4SS conduit (Waksman, 2019). As the transfer strand is transported, both replacement and complementary strands are synthesized in the donor cell and recipient cell, respectively, yielding two copies of plasmid.

RP4 is the representative broad-host-range (BHR) selftransmissible plasmid belonging to IncP-1 $\alpha$ incompatibility group whose sequence has been completed in 1994 (Pansegrau et al., 1994a). The life cycle of RP4 is largely independent of host factors, and its gene expression is regulated by a complex transcriptional circuit composed of autogenous transcription factors, namely, the global regulators KorA, KorB, KorC, and TrbA that bind at multiple sites on RP4 and the local DNA binding proteins such as TraJ and TraK (Thomas, 2000; Bingle and Thomas, 2001). The nature of negative regulation implies a transient expression of plasmid genes during conjugative transfer until the repressors reach a sufficient level in a new host cell (Thomas, 2000, 2006), but the actual range of induction has not been shown experimentally.

Transcriptomic analyses have revealed unprecedented aspects of plasmid biology, especially in crosstalks between plasmids and chromosomes (Nojiri, 2013; Vial and Hommais, 2020). We have been studying the impact of plasmid carriage on the regulatory network of host bacteria through plasmid-encoded elements (Miyakoshi et al., 2007; Shintani et al., 2010). Our studies have led to the discovery of a chromosomal ParA ATPase homolog that is encoded in a genomic island resided in P. putida strain KT2440 and inhibits the partitioning of a specific class of plasmid (Miyakoshi et al., 2007, 2012). A comparison of plasmid transcriptomes in several host bacteria have also shown that expression of plasmid genes is variable depending on the host genetic background (Miyakoshi et al., 2009; Shintani et al., 2011). By using the promiscuous plasmid RP4, we expected to detect drastic expression changes of plasmid genes in much broader range of host strains.

Originally proposed in Jacob and Wollman (1956), zygotic induction is the transient transcriptional activation that takes place in the early stages of conjugative transfer in recipient cells (Bagdasarian et al., 1992; Jones et al., 1992). This phenomenon is attributed to either stimulation of single-stranded promoters on the transfer strand, which are silenced by synthesis of the complementary strand (Masai and Arai, 1997; Bates et al., 1999) or derepression of plasmid genes in a shortage of plasmidspecified repressors. Taking advantage of RNA polymerase inhibitor rifampicin (Rif), the pioneering study in ColIb-P9 conjugative plasmid has detected zygotic induction of plasmid genes in recipient cells (Althorpe et al., 1999). These studies prompted us to comprehensively analyze temporal RNA products during conjugative transfer in vivo. To this end, we performed transcriptome analysis of the very efficient self-transmissible plasmid RP4 in the mating between rifampicin-resistant ( $\mathrm{Rif}^{\mathrm{R}}$ ) and -sensitive $\left(\mathrm{Rif}^{\mathrm{s}}\right)$ strains, and successfully showed not only the zygotic induction in de novo transconjugant cells but also the expression of relaxosome components in the donor cells during conjugative transfer.

\section{MATERIALS AND METHODS}

\section{Bacterial Strains}

Pseudomonas putida strain KT2440 (ATCC47054) was used as the host of plasmid RP4. P. putida strain KT2442 is a spontaneous $\mathrm{Rif}^{\mathrm{R}}$ mutant of KT2440, whose $r p o B$ gene acquired an A to $\mathrm{G}$ mutation at the $1,553 \mathrm{rd}$ nucleotide (Gln518Arg).

Bacterial cells were aerobically grown in $\mathrm{LB}$ medium at $30^{\circ} \mathrm{C}$. The following antibiotics were added to the media: kanamycin (Km, $50 \mu \mathrm{g} / \mathrm{ml}$ ), rifampicin (Rif, $100 \mu \mathrm{g} / \mathrm{ml}$ ). For plate cultures, the above media were solidified with $1.5 \%$ agar (wt/vol).

\section{RNA Extraction From Conjugating Cells}

Each donor or recipient strain grown overnight was inoculated into a fresh 5-ml LB medium by 100 -fold dilution. The cells grown to stationary phase $\left(\mathrm{OD}_{600}\right.$ of 2.0$)$ were harvested by centrifugation and resuspended into $500 \mu \mathrm{l}$ of LB medium containing Rif. After mixing the donor and recipient cells in combinations of $\mathrm{Rif}^{\mathrm{R}}$ and $\mathrm{Rif}^{\mathrm{S}}$ isogenic strains, $100 \mu \mathrm{l}$ of each mixture was immediately spotted on a sterile cellulose acetate membrane filter with $0.45-\mu \mathrm{m}$ pore size (Advantec), which was placed onto LB agar plate containing Rif to allow the cells to conjugate at $30^{\circ} \mathrm{C}$ for $10 \mathrm{~min}$. As controls, we spotted each donor or recipient cells separately on membrane filters, which were separately placed onto LB agar plate containing Rif and incubated at $30^{\circ} \mathrm{C}$ for $10 \mathrm{~min}$.

The cells were released from the filter by vortexing in $1 \mathrm{ml}$ of RNAprotect Bacteria Reagent (Qiagen), and the total RNA was extracted and purified using RNeasy Mini kit (Qiagen) according to the manufacturer's instruction. The total RNA was treated by TURBO DNase (Ambion) at $37^{\circ} \mathrm{C}$ for $30 \mathrm{~min}$ and purified by RNeasy Cleanup (Qiagen). The RNA integrity was checked using 2100 Bioanalyzer (Agilent).

\section{Microarray Analysis}

RNA samples were independently extracted in duplicate and subjected to NimbleGen oligonucleotide microarray (Roche Diagnostics). The custom microarray contains six pairs of 60-mer probes that hybridize with each of the 5,540 genes from the $P$. putida KT2440 chromosome and RP4 plasmid 
genomes. The cDNA synthesis, hybridization, and scanning were performed by Roche Diagnostics. The microarray data were analyzed by NANDEMO analysis software (Roche Diagnostics). The expression change during the 10 -min conjugative transfer was calculated by the ratio of transcript levels in the RNA sample from the mixture of donor and recipient cells to the sum of the equal amount of two RNA samples, which are independently extracted from the donor and recipient cells.

\section{Reverse Transcription-Quantitative PCR (RT-qPCR)}

Total RNA was extracted as described above. Reverse transcription was performed in $20-\mu 1$ solution of $1 \times$ First Strand Buffer containing $5 \mu \mathrm{g}$ of total RNA, $125 \mathrm{ng}$ of random primers (Invitrogen), $5 \mathrm{mM}$ DTT, $0.5 \mathrm{mM}$ dNTPs, $40 \mathrm{U}$ of RNaseOUT (Invitrogen), and $200 \mathrm{U}$ of SuperScript III (Invitrogen). After the RNA and random primers were denatured at $70^{\circ} \mathrm{C}$ for $10 \mathrm{~min}$ and annealed at $25^{\circ} \mathrm{C}$ for $10 \mathrm{~min}$, the remaining reagents were added, and the mixture was incubated at $25^{\circ} \mathrm{C}$ for $10 \mathrm{~min}, 50^{\circ} \mathrm{C}$ for $60 \mathrm{~min}$, and then held at $70^{\circ} \mathrm{C}$ for $15 \mathrm{~min}$ to inactivate the enzymes.

qPCR was performed using MiniOpticon real-time PCR system (BioRad). Each 20- $\mu$ l reaction mixture contained $10 \mu \mathrm{l}$ of $2 \times$ SYBR Premix ExTaq (Takara), $200 \mathrm{nM}$ concentrations of each specific primers and the appropriately diluted cDNA. The primer pairs used for qPCR were as follows: 16S-F (5'-ACACGGT CCAGACTCCTACG- $\left.3^{\prime}\right)$ and 16S-R (5'-TACTGCCCTTCCTCC CAACT- $\left.{ }^{\prime}\right), \quad$ klcA-F $\left(5^{\prime}\right.$-TTCAAATCCCCTCCCCTATC-3') and klcA-R (5'-CCATCCAGCCGAATACCAG-3'), and traJ-F $\left(5^{\prime}\right.$-CCTTCCAGACGAACGAAGAG- $\left.3^{\prime}\right)$ and traJ-R (5'-GAC GTGCTCATAGTCCACGA- $3^{\prime}$ ). The reaction condition was as follows: $95^{\circ} \mathrm{C}$ for $10 \mathrm{~s}$ for enzyme activation and 40 cycles of $95^{\circ} \mathrm{C}$ for $10 \mathrm{~s}$ and $60^{\circ} \mathrm{C}$ for $20 \mathrm{~s}$. A melting curve analysis was performed to verify the amplification specificity. To quantify the transcription of each gene, the copy number was determined by generating a standard curve using a series of 10 -fold dilutions (from $100 \mathrm{pM}$ to $1 \mathrm{fM}$ ) of the target PCR product. For sample normalization, 16S rRNA was used as an internal standard. All of the reactions were performed in triplicate, and the data were normalized using the average of the internal standard.

\section{5'RACE}

5'RACE was performed according to the method described in Bensing et al. (1996). Briefly, $6 \mu \mathrm{g}$ of total RNA was treated with $75 \mathrm{U}$ of tobacco pyrophosphatase (TAP; Nippon Gene) at $37^{\circ} \mathrm{C}$ for $30 \mathrm{~min}$ in the presence of $20 \mathrm{U}$ of RNaseOUT. The TAP-treated and -untreated RNA samples were mixed with the RNA oligonucleotide (5'-AUAUGCGCG AAUUCCUGUAGCUAGAAGAAA- $3^{\prime}$ ) and ligated by $40 \mathrm{U}$ of T4 RNA ligase (TAKARA Bio) at $16^{\circ} \mathrm{C}$ overnight. The ligated RNA samples were mixed with 1 pmol of genespecific primer traJ-R2 (5'-TCTCTTCGATCTTCGCCAGC-3') and reverse transcribed by $100 \mathrm{U}$ of SuperScriptIII at $50^{\circ} \mathrm{C}$ for $60 \mathrm{~min}$ in the presence of $20 \mathrm{U}$ of RNaseOUT. The cDNA fragment spanning the ligated RNA oligonucleotide and the $5^{\prime}$ end of traJ transcript was amplified by KOD-Plus highfidelity DNA polymerase (TOYOBO) using primers Oligo-F1 ( $5^{\prime}$ TATGCGCGAATTCCTGTAGC-3' $)$ and traJ-R. The amplified fragment was cloned into HincII-digested pBluescript II SK(-) vector (Stratagene), and the inserts from several clones were sequenced using M13 primers.

\section{RESULTS AND DISCUSSION}

\section{Experimental Design}

A conjugative plasmid is transferred from a donor cell to a recipient cell, the latter of which turns into an active transconjugant cell through zygotic induction of plasmid genes. The first conjugative transfer triggers a chain reaction of plasmid transfer from the de novo transconjugant cells to next recipient cells (Figure 1). The initial contact between the donor and recipient cells is stochastic, and the conjugation events cannot be synchronized. However, the very high transfer efficiency of RP4 between P. putida KT2440 (Bingle et al., 2003) allows maximizing the population of transconjugants in the mixture of cells. Given that the conjugative transfer of plasmids is conducted at the rate of $45 \mathrm{~kb} / \mathrm{min}$ (as in the case of E. coli Hfr) (Lawley et al., 2004), the $60-\mathrm{kb}$ RP4 plasmid can be transferred in $1.3 \mathrm{~min}$ and is sufficient to accomplish a single round of transfer within $10 \mathrm{~min}$. In our conjugation experiment, $\sim 1 \times 10^{9}$ cells of donor and recipient were mixed equally and allowed for mating on the filter membrane for $10 \mathrm{~min}$. RP4 was transferred between isogenic KT2440 strains at the efficiency of $>1 \times 10^{-1}$ (CFU ratio of transconjugant/recipient), indicating that $>10 \%$ of recipient cells acquired the plasmid in $10 \mathrm{~min}$.

For simplicity, this study utilized the custom microarray containing both genomes of KT2440 chromosome and RP4 plasmid to analyze the conjugative transfer between the cells with the same genetic background. Assuming that there are no expression changes between transconjugant and donor cells, the transcript level of each RP4 gene is estimated to raise by twofold at the maximum when the transfer efficiency is $100 \%$ (the number of transconjugant cells is equal to that of donor cells). Cell growth can be ignored within the 10-min filter mating since the cells on the membrane filter are concentrated 10-fold from the stationary-phase cultures. Therefore, we set the threshold at fourfold change for upregulation of gene expression during conjugative transfer.

Although the donor and resultant transconjugant cells are genetically identical, transcription of plasmid genes in either cell is distinguishable using Rif and combinations of Rif ${ }^{\mathrm{R}}$ and Rif $\mathrm{f}$ isogenic strains, which are only different in $r p o B$ (Figure 1). It has been known for $\mathrm{F}$ plasmid that the established $\mathrm{Rif}^{\mathrm{S}}$ donors can transfer the plasmid into the recipients, while the Rif $^{S}$ recipients fail to accomplish the plasmid transfer in the presence of Rif, indicating that de novo expression in the donor cells is dispensable for initiation of conjugative transfer (Wilkins and Hollom, 1974; Kingsman and Willetts, 1978). Similarly, our mating experiment in the 1:1 mixture of RP4 donor and recipient cells in the presence of Rif showed that the transfer efficiency of $\mathrm{Rif}^{\mathrm{S}}$ donors was no greater than that of $\mathrm{Rif}^{\mathrm{R}}$ donors and that 

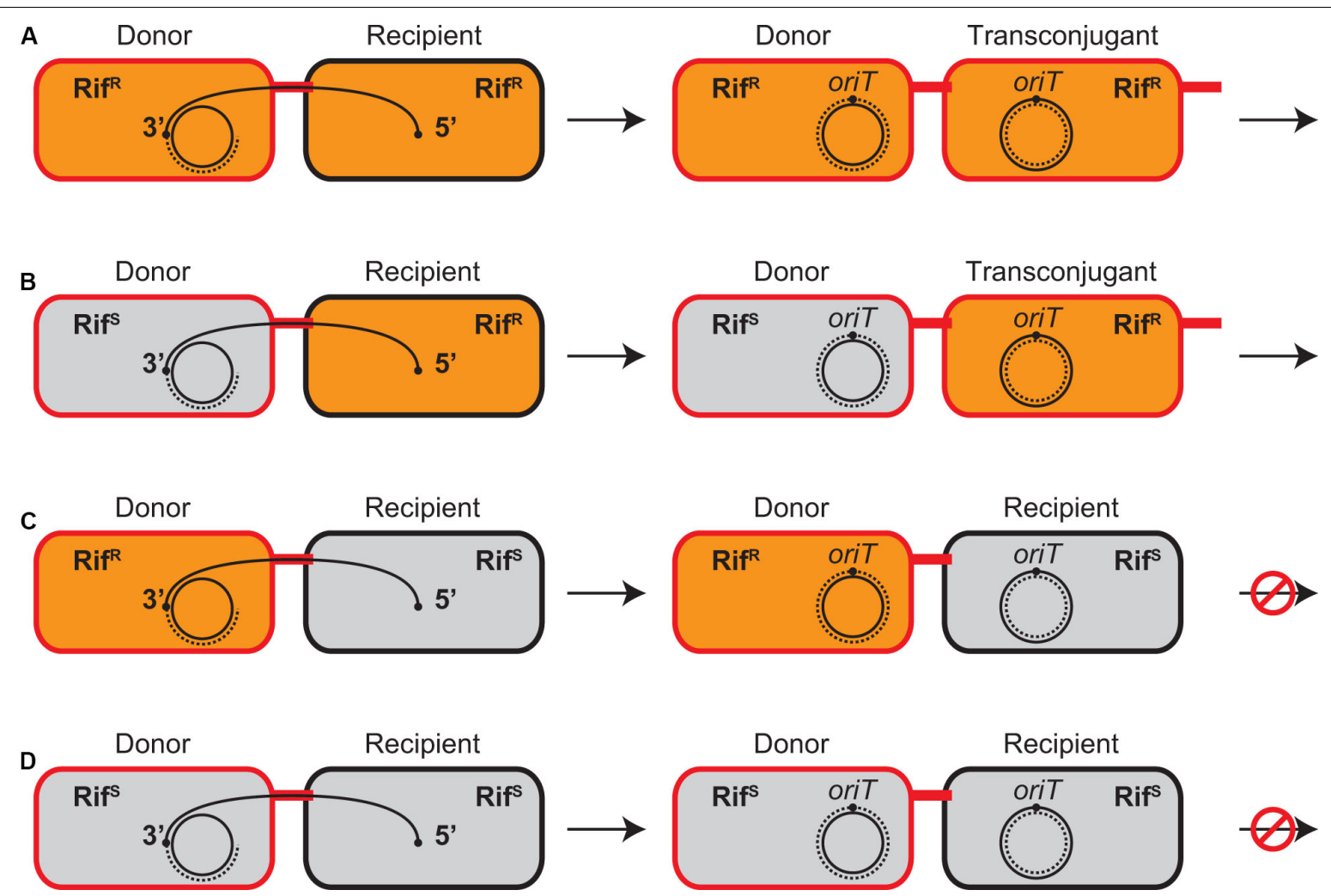

FIGURE 1 | Conjugative transfer between combinations of Rif ${ }^{\mathrm{R}}$ and $\mathrm{Rif}^{\mathrm{S}}$ strains in the presence of Rif. Rif ${ }^{\mathrm{R}}$ and Rif $\mathrm{f}^{\mathrm{S}}$ cells are shown as orange and gray bacilli, respectively. The donor and transconjugant cells proficient in plasmid transfer are indicated in red while the recipient cells are indicated in black. The transfer strand is represented as a solid curve and its oriT sites are indicated by black dots, which is transferred from the donor to the recipient in a direction from $5^{\prime}$ to $3^{\prime}$. The replacement and complementary strands are represented as broken lines. (A) Both donor and recipient are Rif ${ }^{\mathrm{R}}$. (B) When recipient is Rif ${ }^{\mathrm{R}}$, Rif does not prevent plasmid transfer from $\mathrm{Rif}^{\mathrm{S}}$ donor and new transconjugant is established. (C) When recipient is Rif ${ }^{\mathrm{S}}$, Rif prevents establishment of transconjugant but not transcription in $\mathrm{Rif}^{\mathrm{R}}$ donor. (D) Both donor and recipient are Rif ${ }^{\mathrm{S}}$. No transcription is initiated in the presence of Rif.

neither donor strains were able to establish transconjugants in Rif recipients (data not shown).

\section{Zygotic Induction in de novo Transconjugant Cells}

The mating between the Rif ${ }^{S}$ donor and $\mathrm{Rif}^{\mathrm{R}}$ recipient strains generates the new $\mathrm{Rif}^{\mathrm{R}}$ transconjugant strain, which is genetically identical to the $\mathrm{Rif}^{\mathrm{R}}$ donor strain and continues conjugative transfer to the next recipient cells. Therefore, this combination is virtually identical to the mating between the Rif ${ }^{\mathrm{R}}$ donor and $\mathrm{Rif}^{\mathrm{R}}$ recipient strains irrespective of the initial donor's genetic background (Figures 1A,B), although the number of resultant $\mathrm{Rif}^{\mathrm{R}}$ donor cells is apparently smaller than the latter combination. We successfully detected the transcription upregulation of many plasmid genes in the de novo transconjugant cells in these two combinations (Table 1). The fold changes were generally smaller in the combination of $\mathrm{Rif}^{\S}$ donor and $\mathrm{Rif}^{\mathrm{R}}$ recipient (the second column) than that of $\mathrm{Rif}^{\mathrm{R}}$ donor and $\mathrm{Rif}^{\mathrm{R}}$ recipient (the first column). This result is likely to reflect the number of active transconjugant cells in the population.

Our microarray analysis clearly showed strong zygotic induction specifically on the leading region of transfer strand, namely, kfrABC, korA-incC-korBFG, klaABC, and kleABCDEF operons, which are involved in stable inheritance of the plasmid (Wilson et al., 1997; Adamczyk et al., 2006). Since the leading region enters into the recipient cells in the early stage (Figure 2), the zygotic induction of these operons might be advantageous to the plasmid establishment in the new recipient cells. Among the induced operons, the kor operon encodes the KorA and KorB transcriptional regulators, which bind to 7 and 12 operator sequences on RP4, respectively (Kornacki et al., 1993; Jagura-Burdzy and Thomas, 1994, 1995; Jagura-Burdzy et al., 1999b; Kostelidou et al., 1999; Kostelidou and Thomas, 2000, 2002; Bingle et al., 2005; Chiu et al., 2008). Between korA and korB genes, the operon also encodes the IncC plasmid partitioning ATPase, which interacts with KorB (Motallebi-Veshareh et al., 1990; Jagura-Burdzy et al., 1999a; Rosche et al., 2000). Zygotic induction of KorA and KorB repressors suggests that these global regulators together allow only a temporal expression of their target genes on RP4 in the early stage of conjugative transfer. Interestingly, chromatin immunoprecipitation analysis has revealed that KorB transcriptional regulator from RP4 binds on an operator sequence found in P. putida KT2440 chromosome (Chiu and Thomas, 2004). However, we found no chromosomal genes that 
TABLE 1 | Expression changes of RP4 genes during conjugative transfer.

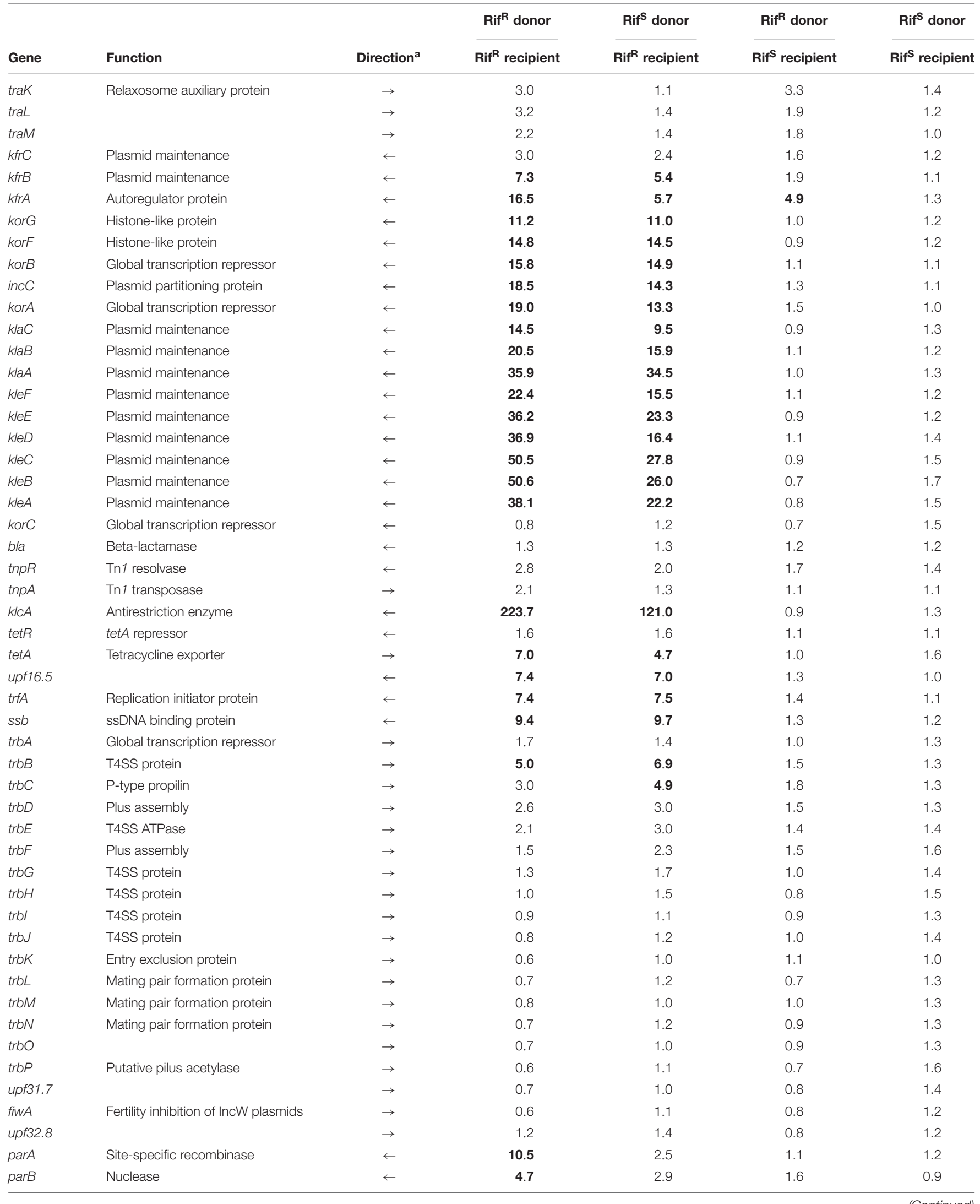


TABLE 1 | Continued

\begin{tabular}{|c|c|c|c|c|c|c|}
\hline & & & Rif $^{\mathrm{R}}$ donor & $\mathrm{Rif}^{\mathrm{S}}$ donor & Rif $^{\mathrm{R}}$ donor & Rif ${ }^{S}$ donor \\
\hline parD & Antitoxin protein & $\rightarrow$ & 6.8 & 3.5 & 2.9 & 1.3 \\
\hline parE & Toxin protein & $\rightarrow$ & 6.7 & 4.7 & 3.3 & 1.2 \\
\hline ist $A$ & IS21 transposase & $\rightarrow$ & 3.7 & 2.4 & 2.3 & 1.1 \\
\hline $\operatorname{tra} A$ & & $\leftarrow$ & 0.9 & 0.8 & 0.6 & 1.2 \\
\hline $\operatorname{traB}$ & & $\leftarrow$ & 1.0 & 1.1 & 0.9 & 1.4 \\
\hline $\operatorname{traC1}$ & DNA primase & $\leftarrow$ & 1.0 & 1.0 & 1.3 & 1.5 \\
\hline traC2 & DNA primase & $\leftarrow$ & 0.8 & 1.1 & 1.3 & 1.4 \\
\hline $\operatorname{traD}$ & & $\leftarrow$ & 1.1 & 1.1 & 1.6 & 1.2 \\
\hline traH & Relaxosome auxiliary protein & $\leftarrow$ & 21.1 & 6.3 & 15.4 & 1.2 \\
\hline traJ & Relaxosome auxiliary protein & $\leftarrow$ & 15.1 & 2.6 & 6.0 & 1.1 \\
\hline
\end{tabular}

The RP4 gene name and direction of transcription relative to the direction of transfer are indicated on the left columns. Combinations of donor and recipient strains are indicated in the upper rows. ${ }^{a}$ The direction of transcription corresponds to that shown in Figure 2. $\leftarrow$, mRNA is transcribed from the transfer strand as template; $\rightarrow$, mRNA is transcribed from the complementary strand as template. Fold changes $>4.0$ are shown in bold.

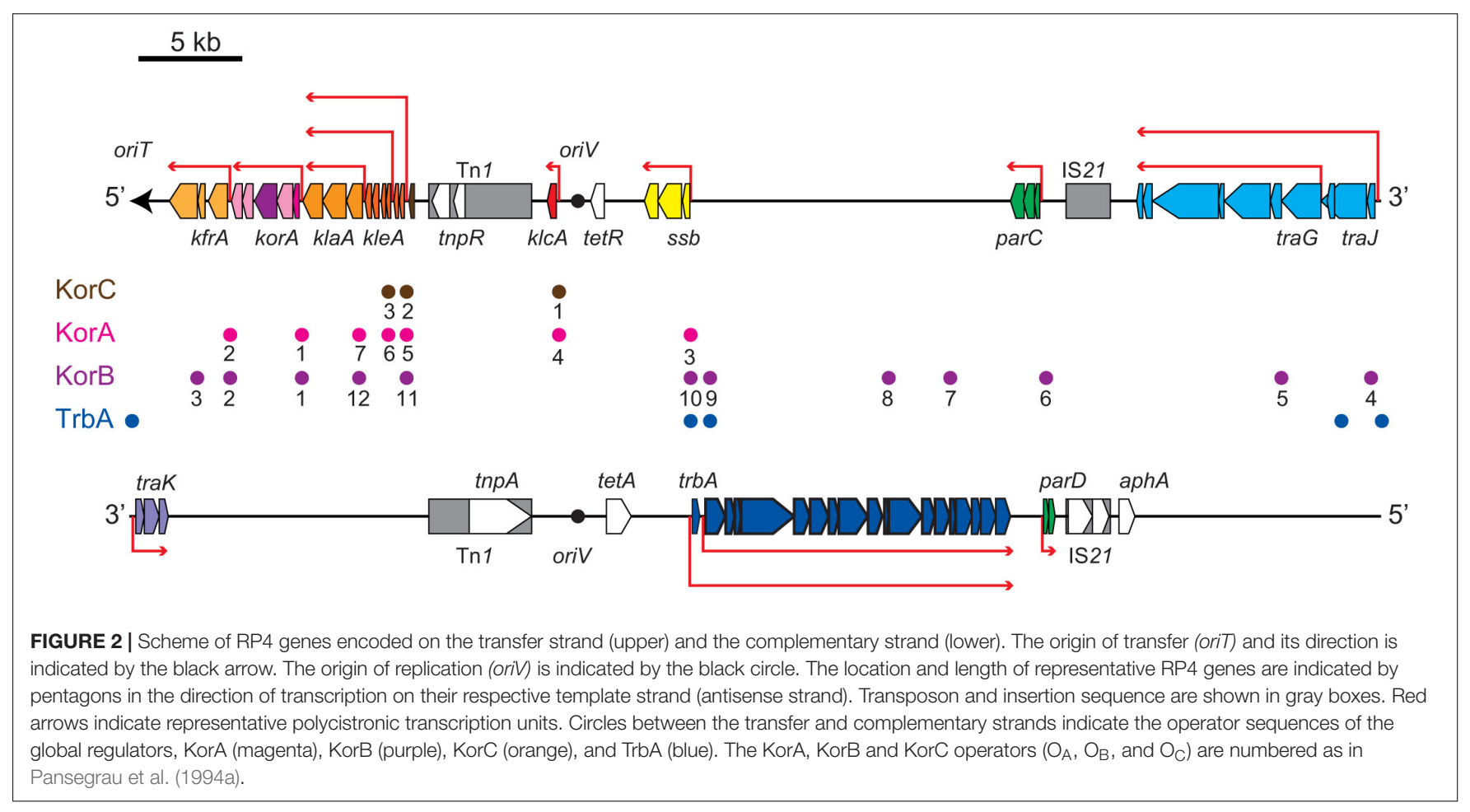

exhibit significant changes in common in our microarray data (data not shown).

The most strongly induced gene was $k l c A$, which is encoded $\sim 20 \mathrm{~kb}$ away from oriT on the transfer strand. Under steadystate conditions, $k l c A$ was transcribed at one of the lowest basal levels among the RP4 genes (Supplementary Table S1), which is attributable to the strong repression by KorA and KorC (Figurski et al., 1982; Thomas et al., 1988; Kornacki et al., 1993). The KlcA protein has recently been shown to exhibit an antirestriction activity (Goryanin et al., 2018). RT-qPCR analysis confirmed that the $k l c A$ transcript is induced $\sim 120$-fold in the transconjugant cells (Figure 3A). The surge of KlcA expression might be 
$k / c A$

A

0.25

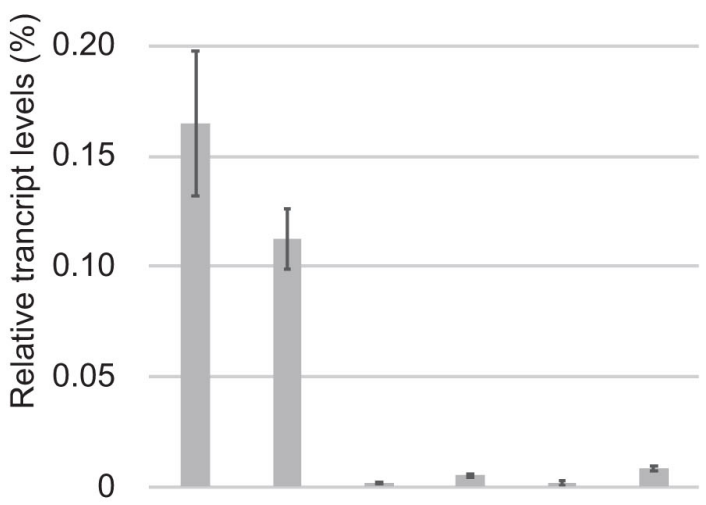

Recipient: Rif ${ }^{R}$ RifR Rifs RifS - -

Donor: RifR Rifs RifR Rifs RifR Rifs
traJ

B

0.006

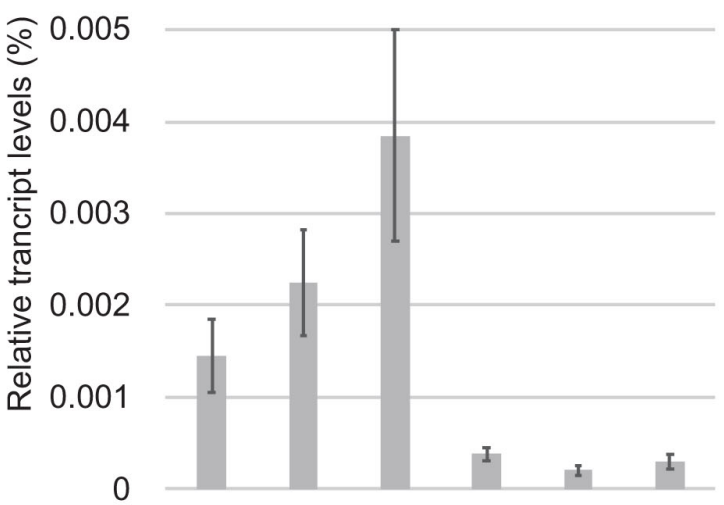

Recipient: RifR RifR Rifs Rifs - -

Donor: RifR Rifs RifR Rifs RifR Rifs

FIGURE 3 | Quantitative RT-PCR analysis of zygotic induction. The transcript levels of $k / C A$ (A) and traJ (B) mRNAs relative to 16S rRNA are shown. The combinations of $\mathrm{Rif}^{\mathrm{R}}$ and $\mathrm{Rif}^{\mathrm{S}}$ strains for donor and recipient of RP4 are indicated below. The two bars on the right are control samples of donor cells only.

beneficial to prevent the cleavage of double-stranded plasmid DNA by restriction enzymes in a new host. It is important to note that not all the genes on the transfer strand were induced during the conjugation, e.g., bla and korC. This result is in line with the fact that $\operatorname{Tn} 1$ transposon insertion interrupts the transcription of $k l c A$ operon and the constitutive bla mRNA reads through the downstream korC gene in IncP- $1 \alpha$ plasmids (Kornacki et al., 1990). The constitutively expressed KorC might be responsible for the very low basal level of $k l c A$ transcript.

We also observed the zygotic induction of $\operatorname{trf} A$ operon, which is composed of $s s b, \operatorname{trf} A$, and upf16.5 (Table 1). The $\operatorname{trf} A p$ promoter is strongly repressed by KorA and KorB proteins cooperatively by binding at $\mathrm{O}_{\mathrm{B}} 10$ (Jagura-Burdzy and Thomas, 1994, 1997; Jagura-Burdzy et al., 1999b). The $\mathrm{O}_{\mathrm{B}} 10$ site exhibits the highest affinity for KorB (Kostelidou and Thomas, 2000). The trfA gene expresses two isoforms both of which bind on the oriV region to initiate vegetative plasmid replication (Pansegrau et al., 1994a; Thorsted et al., 1996). The first gene ssb encodes the singlestranded DNA (ssDNA) binding protein, which is probably involved in vegetative replication of RP4 (Jovanovic et al., 1992) or might play a role in conjugative transfer by protecting the transferred ssDNA. The zygotic induction of SSB encoded in the leading region has also been observed in $\mathrm{F}$ and ColIb-P9 conjugative plasmids (Bagdasarian et al., 1992; Jones et al., 1992; Althorpe et al., 1999) through stimulation of single-stranded promoters (Masai and Arai, 1997; Bates et al., 1999; Nasim et al., 2004). However, we have not identified such promoters for the zygotically induced RP4 genes so far.

On the complementary strand, we detected a modest induction of the trb operon encoding the components for $\mathrm{Mpf} / \mathrm{T} 4 \mathrm{SS}$ to transport the plasmid ssDNA linked with the relaxosome protein complex. The trb operon has two promoters, trbAp and trbBp, and can be transcribed only after the template strand is replicated in the new transconjugant cells. The relatively strong trbBp responsible for the transcription of trb operon is cooperatively repressed by $\operatorname{TrbA}$ and KorB, i.e., KorB alone represses trbBp only weakly by binding at OB 9 (Zatyka et al., 1997, 2001; Bingle et al., 2003, 2005). $\operatorname{trbAp}$ is located face-to-face with the strong $\operatorname{trfAp}$ promoter, which inhibits the activity of $\operatorname{tr} b A p$ via elongating transcription complexes in the opposite direction. $\operatorname{trb} A p$ can be activated through inhibition of counteracting trfAp by KorA and KorB proteins (Jagura-Burdzy and Thomas, 1994, 1997; Jagura-Burdzy et al., 1999b), implying that transcription of $\operatorname{trb} A$ is allowed after the repression of $\operatorname{trfAp}$ is completed. Therefore, we could only detect zygotic induction of transcripts originated from trbBp, and transcription from the upstream promoter trbAp was not induced in $10 \mathrm{~min}$. Moreover, the induction rate went down below the threshold as the transcription proceeded into downstream genes (Table 1). We expect to detect the late induction of trb operon at higher levels by increasing the duration of filter mating.

Both the divergently transcribed parCBA and parDE operons encoding the multimer resolution system and the postsegregational killing system, respectively, contribute to the stable inheritance of RP4 plasmid (Gerlitz et al., 1990; Roberts and Helinski, 1992; Eberl et al., 1994; Jovanovic et al., 1994; Roberts et al., 1994; Sia et al., 1995). Autogenous regulation of the divergent promoters by ParA and ParD (Davis et al., 1992; Eberl et al., 1992) accounts for the modest induction of this locus in the transconjugant cells (Table 1), while this locus contains a low-affinity binding site for $\operatorname{KorB}\left(\mathrm{O}_{\mathrm{B}} 6\right)$ 
whose contribution to transcription regulation remains unknown (Kostelidou and Thomas, 2000).

\section{Zygotic Induction in Donor Cells}

The trailing region, which enters the recipient in the end of plasmid transfer, harbors the traJIHGFEDCBA operon encoding the components of relaxosome and other Dtr proteins. Upon binding of auxiliary proteins TraJ and TraK at oriT, TraI relaxase is recruited to oriT to form the relaxosome (Fürste et al., 1989). Binding of TraJ protein at the 19-bp inverted repeat interspaced by 8 bp to the nic site is required for the strand-specific cleavage by TraI relaxase (Ziegelin et al., 1989; Pansegrau et al., 1990b). The interaction of TraJ and TraI at oriT is stabilized by the acidic protein $\mathrm{TraH}$, which is encoded in a different reading frame within the traI gene, to form the relaxosome nucleoprotein structure (Pansegrau et al., 1990a). TraI cleaves the nic site in a site- and strand-specific manner and covalently binds with the $5^{\prime}$ end of the transfer strand at its 22nd tyrosine residue (Y22) in the catalytic center. The relaxosome is recruited to T4SS by the coupling protein TraG (Balzer et al., 1994; Schröder et al., 2002; Schröder and Lanka, 2003).

The tra operon is transcribed from the upstream traJp and downstream traGp promoters (Figure 2). Importantly, the relaxase gene traI is solely transcribed from traJp, while the coupling protein gene traG is transcribed in two different mRNAs. Microarray analysis revealed a strong induction of traJ, traI, and traH genes in the mating between the $\mathrm{Rif}^{\mathrm{R}}$ recipient and $\mathrm{Rif}^{\mathrm{R}}$ donor cells (Table 1). Unexpectedly, in the mating between the Rif ${ }^{S}$ recipient and $\mathrm{Rif}^{\mathrm{R}}$ donor, where the conjugative transfer reaction stops after the first reaction (Figure 1C), we observed specific induction of traJ, traH, and traI but not the other RP4 genes. Because no transcription can be initiated in Rif ${ }^{S}$ transconjugant cells in the presence of Rif, this result indicates that traJp is activated in donor cells during conjugative transfer. Indeed, we found no plasmid genes that showed significant expression changes in the combination of Rif ${ }^{S}$ donor and Rif recipient (the rightmost column of Table $\mathbf{1}$ ). We verified by RTqPCR analysis that the traJ transcript was strongly induced in the conjugating $\mathrm{Rif}^{\mathrm{R}}$ donor cells (Figure $3 \mathrm{~B}$ ). The transcriptional induction of traJ was also observed in the mixture of the Rif ${ }^{5}$ donor and $\mathrm{Rif}^{\mathrm{R}}$ recipient cells, which might reflect the expression in the new $\mathrm{Rif}^{\mathrm{R}}$ transconjugant cells.

The oriT of RP4 contains divergent promoters, traJp and traKp, which are regulated by a complex of multiple regulatory proteins (Figure 4). Binding of TraJ protein at the 19-bp inverted repeat causes autorepression of traJp (Zatyka et al., 1994). TraK protein binds the intrinsically curved $\sim 200$-bp oriT region downstream of traKp (Ziegelin et al., 1992) and represses both traJ and traK (Zatyka et al., 1994). In addition, TrbA binds at two sites overlapping the -35 boxes of traJp and traKp (Bingle et al., 2003). traGp is repressed by KorB through binding its operator sequence $\left(\mathrm{O}_{\mathrm{B}} 4\right)$ in the traJ-traI intergenic region without affecting the activity of traJp (Bingle et al., 2005). Interestingly, the transcription initiation site of traJ has been reported to locate at the G nucleotide 24-nt upstream of the nic site (Greener et al., 1992; Zatyka et al., 1994). Given that the first $24 \mathrm{nt}$ of $5^{\prime}$ untranslated region of traJ is encoded on the transfer strand (Figure 4), it is impossible to transcribe traJ in the

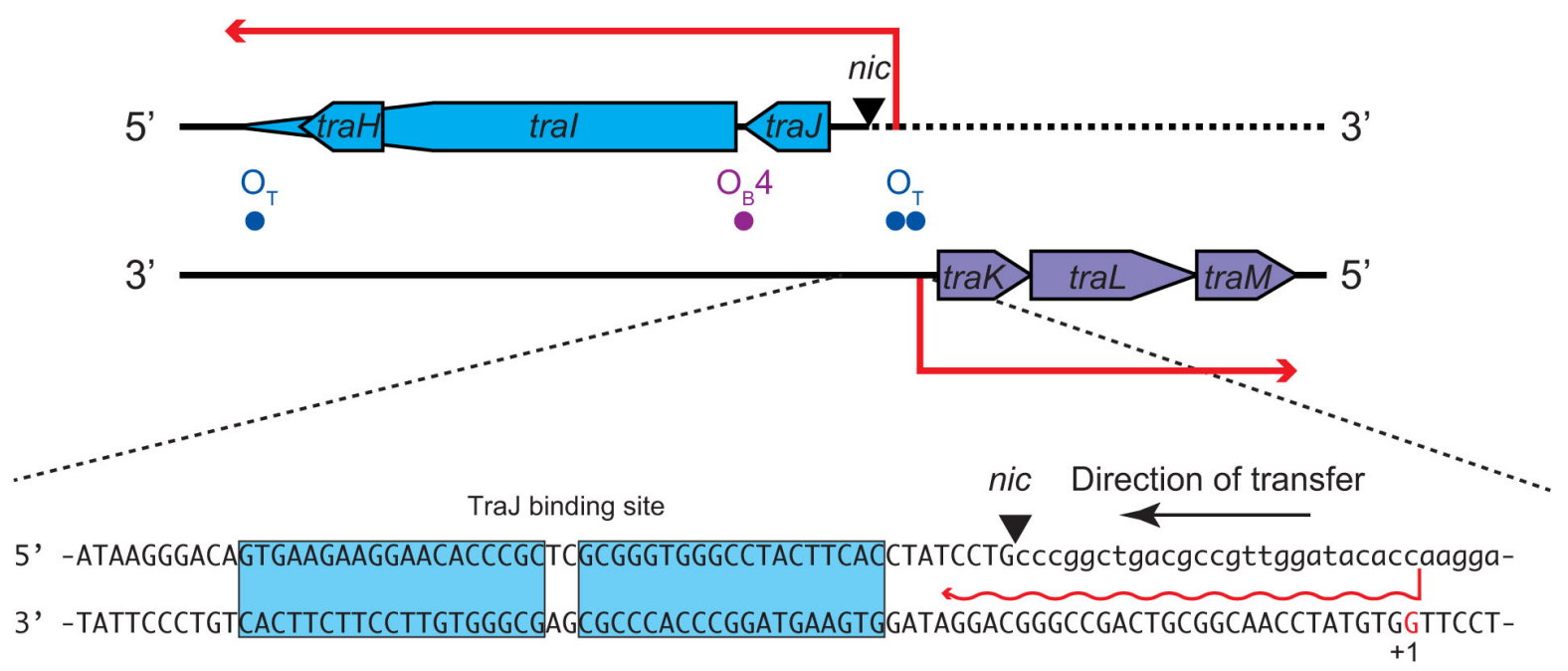

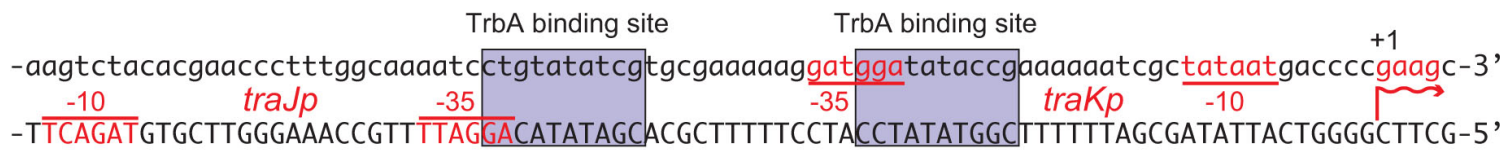

FIGURE 4 | Nucleotide sequence of the oriT region of RP4 plasmid. The nic site cleaved by Tral is indicated by the triangle. The nucleotides of the transfer strand which are transported into recipient first are written in lowercase. The transcription start sites and promoter sequences as previously reported (Zatyka et al., 1994) are indicated as $+1,-10$, and -35 , respectively, on each non-template strand. The TraJ and TrbA binding sites are boxed. The binding site of TraK is located downstream of traK transcription start site (not shown). 
absence of the leader region of the transfer strand. Our $5^{\prime} \mathrm{RACE}$ analysis verified that the traJ transcripts were homogeneously accumulated in the donor cells during conjugative transfer and started from the same nucleotide as previously reported (data not shown). Therefore, it is most likely that the tra operon is induced in the donor cell immediately after regeneration of the traJ promoter from the $3^{\prime}$ end of oriT, which in itself dissociates the autogenous repressor proteins from oriT. Since TraI associates with both ends of oriT to circularize the plasmid under steady-state conditions, we envisage that the oriT region becomes accessible to replication and transcription machineries after the relaxosome complex is transferred into the recipient cell.

\section{A Model of Continuous Plasmid Transfer by Induction of Relaxase Operon}

Conjugative transfer accompanies rolling-circle replication (RCR) to generate two identical copies of plasmid DNA in recipient and donor cells (Willetts and Wilkins, 1984; Lanka and Wilkins, 1995). As the transfer strand is initially cleaved and bound with a relaxase, both replacement strand and complementary strand are synthesized in the cells, which are directly connected but segregated by the membranes. In the recipient cell, the $5^{\prime}$ and $3^{\prime}$ ends of the transfer strand are ligated and recircularized by the relaxase that is transported together to create a unit-length copy of plasmid DNA, and the complementary strand is replicated from RNA primers, which are presumably generated by a plasmid-encoded DNA primase (Rees and Wilkins, 1990). In the donor cell, the $3^{\prime}$ end of transfer strand acts as a primer for replacement strand synthesis by a DNA polymerase III (Pansegrau et al., 1990b). However, it remains paradoxical in which cell the relaxase executes the second cleavage reaction, which is a prerequisite to generate a unit-length plasmid copy and terminate RCR (Chandler et al., 2013). In the F plasmid transfer system, it has been proposed that the second cleavage reaction is likely to occur in the donor cell rather than in the recipient cell (Dostál et al., 2011). In contrast, the TrwC relaxase of R388 plasmid system has been shown to be transported into the recipient cell and then recircularize the transferred DNA (Draper et al., 2005). Although both TraI $F$ and TrwC relaxases contain helicase domains and are categorized into the same $\mathrm{MOB}_{\mathrm{F}}$ family (Garcillán-Barcia et al., 2009), this inconsistency between the two systems might be attributable to the number of active tyrosine residues required for the cleavage reaction by the relaxase. TrwC employs Y18 for the initial cleavage and Y26 for the second cleavage in the same molecule and, therefore, is capable of the transfer termination in the recipient cell (Gonzalez-Perez et al., 2007). However, among two pairs of tyrosines (Y16, Y17, Y23, and Y24) in its transesterase domain of $\mathrm{TraI}_{\mathrm{F}}$ relaxase, $\mathrm{Y} 16$ is the only residue critical for conjugative transfer (Dostál et al., 2011). Once covalently attached with the $5^{\prime}$ end of ssDNA, the single active tyrosine residue is unable to catalyze the second cleavage reaction, raising the possibility that a second tyrosine residue is provided by another relaxase protomer or is substituted by an alternative nucleophile such as water (Chandler et al., 2013). Recently,
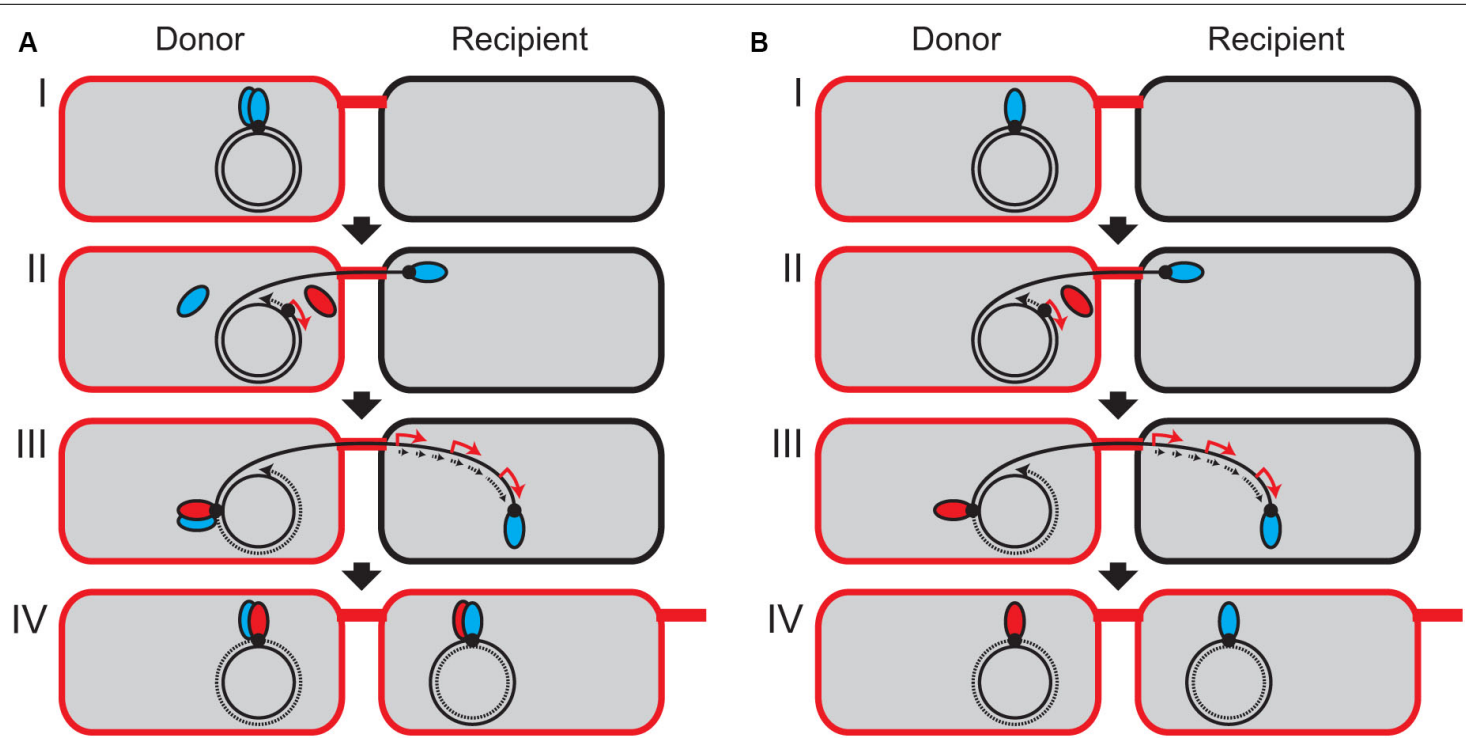

FIGURE 5 | Model of continuous plasmid transfer by induction of relaxase in the donor cell. It has not been experimentally verified whether Tral forms a dimer (A) or a monomer (B) in vivo. (I) At the oriT site (black dot), the Tral relaxase (blue ellipsoid) is covalently bound to the $5^{\prime}$ end of tranfer strand. (II) One relaxase starts to be transported from the donor into the recipient. The $3^{\prime}$ end of transfer strand serves as a primer to initiate the replication of replacement strand (dotted arrow). Since the traJ promoter region is the first to be replicated, the transcription of traJlH operon is temporally stimulated (red arrow) to express the second Tral relaxase (red ellipsoid). It is unknown whether only one Tral molecule has been transported into the recipient cell through the T4SS machinery. (III) In the donor cell, the induced relaxase or the remaining free monomer binds at the oriT site to reconstitute a new relaxosome complex and generates the unit-length ssDNA to terminate the plasmid transfer. In the recipient, the complementary strand is replicated (dotted arrows) and the transcription of plasmid genes are induced (red arrow). (IV) The rolling-circle replication is accomplished in the donor cell, and the transferred strand is recircularized in the recipient cell to be established as the new transconjugant cell. 
it has been solved that the full-length $\mathrm{TraI}_{\mathrm{F}}$ forms a dimer to bind both $5^{\prime}$ and $3^{\prime}$ ends of oriT simultaneously by adopting closed and open conformations, respectively (Ilangovan et al., 2017). This implies that one molecule of TraI $\mathrm{F}_{\mathrm{F}}$ is left behind in the donor cell to cleave the newly synthesized oriT and produce the unit-length plasmid DNA.

In the case of RP4 plasmid transfer system, the TraI relaxase contains only a single tyrosine residue Y22, which catalyzes the cleavage at nic and covalently binds with the $5^{\prime}$ end of the nicked DNA strand (Pansegrau et al., 1993, 1994b). It has been demonstrated by in vitro assay using a magnetic bead technique that TraI existing as a monomer in solution is unable to conduct the second cleavage reaction (Pansegrau and Lanka, 1996). Unlike the $\mathrm{MOB}_{\mathrm{F}}$ family relaxases, the RP4 TraI does not have a helicase activity, and the conformation of TraI bound with oriT ssDNA remains ambiguous. Here, we propose a model that after the relaxase linked with transfer strand is transported into the recipient cell, the expression of the second copy of relaxase is induced at the transcriptional level in the conjugating donor cell to replenish the first relaxase (Figure 5). If the relaxase exists as a dimer in vivo, either the induced relaxase or the remaining monomer is responsible for the second cleavage in the donor cell (Figure 5A). Even if the relaxase exists as a monomer, a small population of TraI molecules could provide a second tyrosine residue for the cleavage of the other plasmid copies (Figure 5B). However, it should be noted that the copy number of RP4 plasmid is estimated at less than three copies in Pseudomonas spp. (Itoh et al., 1984), and the translation of TraI is limiting (Pansegrau et al., 1990a). Further study is required to determine the exact copy number of TraI molecules in the RP4 donor strain and investigate whether or not the induced relaxase is responsible for the second cleavage reaction.

This model is not contradictory to the previous results that de novo expression in the donor cell is dispensable for initiation of conjugative transfer (Wilkins and Hollom, 1974; Kingsman and Willetts, 1978). Pretreatment of donor cells with Rif did not prevent the initiation and termination of plasmid transfer given the presence of free TraI molecules. We also note that this model is not the case for other plasmid systems such as R388 (Draper et al., 2005). Nonetheless, the feature of oriT region with a pair of divergent promoters can often be seen in diverse groups of conjugative plasmids (Lanka and Wilkins, 1995; Francia et al., 2004). It is tempting to speculate that zygotic induction of relaxase in donor cells facilitates conjugative transfer in general.

\section{CONCLUSION}

This study revisited the phenomenon known as zygotic induction during conjugative transfer of plasmid RP4. By transcriptomic analysis, we have detected strong induction of several operons

\section{REFERENCES}

Adamczyk, M., Dolowy, P., Jonczyk, M., Thomas, C. M., and Jagura-Burdzy, G. (2006). The $k f r A$ gene is the first in a tricistronic operon required for survival in the transconjugant cells. This is attributable to derepression of transcription by plasmid-encoded repressor proteins. We have also revealed that the conjugating donor cells induce the transcription of traJIH operon, which is initiated from the oriTproximal promoter. This mechanism shed light on the longstanding question over the requirement of the second relaxase molecule for the termination of conjugative transfer. Since this study has only detected the transcripts in the mixtures of recipient and donor cells, further study is required to visualize the relaxase molecules associated with the plasmid transfer strand in vivo at a single-cell level. Overall, this study provides new insights into the differential regulation of plasmid gene expression in donor and recipient cells during conjugative transfer. Our methodology is applicable for many conjugative plasmids to analyze their dynamic expression in minute detail using current RNA-seq technologies.

\section{DATA AVAILABILITY STATEMENT}

The data are deposited in NCBI's Gene Expression Omnibus (GEO, http://www.ncbi.nlm.nih.gov/geo/) and are accessible through GEO Series accession number GSE146879.

\section{AUTHOR CONTRIBUTIONS}

MM conceived the study, designed and performed the experiments, and wrote the manuscript. YO, YN, and MT contributed to discussion, editing, and revision of the manuscript.

\section{FUNDING}

MM was supported by the JSPS Research Fellowship for Young Scientists (PD). This work was supported by the JSPS KAKENHI JP17H03781 and the University of Tsukuba Basic Research Support Program Type S.

\section{ACKNOWLEDGMENTS}

The authors would like to thank Kouhei Kishida and Masaki Shintani for critical reading.

\section{SUPPLEMENTARY MATERIAL}

The Supplementary Material for this article can be found online at: https://www.frontiersin.org/articles/10.3389/fmicb. 2020.01125/full\#supplementary-material

of IncP-1 plasmid R751. Microbiology 152, 1621-1637. doi: 10.1099/mic.0. 28495-0

Althorpe, N. J., Chilley, P. M., Thomas, A. T., Brammar, W. J., and Wilkins, B. M. (1999). Transient transcriptional activation of the Incll plasmid anti-restriction 
gene $(\operatorname{ard} A)$ and SOS inhibition gene ( $p s i B)$ early in conjugating recipient. Mol. Microbiol. 31, 133-142. doi: 10.1046/j.1365-2958.1999.01153.x

Bagdasarian, M., Bailone, A., Angulo, J. F., Scholz, P., Bagdasarian, M., and Devoret, R. (1992). PsiB, an anti-SOS protein, is transiently expressed by the F sex factor during its transmission to an Escherichia coli K-12 recipient. Mol. Microbiol. 6, 885-893. doi: 10.1111/j.1365-2958.1992.tb01539.x

Balzer, D., Pansegrau, W., and Lanka, E. (1994). Essential motifs of relaxase (TraI) and TraG proteins involved in conjugative transfer of plasmid RP4. J. Bacteriol. 176, 4285-4295. doi: 10.1128/jb.176.14.4285-4295.1994

Bates, S., Roscoe, R. A., Althorpe, N. J., Brammar, W. J., and Wilkins, B. M. (1999). Expression of leading region genes on IncI1 plasmid ColIb-P9: genetic evidence for single-stranded DNA transcription. Microbiology 145, 2655-2662. doi: 10.1099/00221287-145-10-2655

Bensing, B. A., Meyer, B. J., and Dunny, G. M. (1996). Sensitive detection of bacterial transcription initiation sites and differentiation from RNA processing sites in the pheromone-induced plasmid transfer system of Enterococcus faecalis. Proc. Natl. Acad. Sci. U.S.A. 93, 7794-7799. doi: 10.1073/pnas.93.15. 7794

Bingle, L. E. H., Macartney, D. P., Fantozzi, A., Manzoor, S. E., Thomas, C. M., and Karn, J. (2005). Flexibility in repression and cooperativity by KorB of broad host range IncP-1 plasmid RK2. J. Mol. Biol. 349, 302-316. doi: 10.1016/j.jmb.2005. 03.062

Bingle, L. E. H., and Thomas, C. M. (2001). Regulatory circuits for plasmid survival. Curr. Opin. Microbiol. 4, 194-200. doi: 10.1016/S1369-5274(00)00188-0

Bingle, L. E. H., Zatyka, M., Manzoor, S. E., and Thomas, C. M. (2003). Cooperative interactions control conjugative transfer of broad host-range plasmid RK2: full effect of minor changes in TrbA operator depends on KorB. Mol. Microbiol. 49, 1095-1108. doi: 10.1046/j.1365-2958.2003.03620.x

Cabezón, E., Ripoll-Rozada, J., Peña, A., de la Cruz, F., and Arechaga, I. (2015). Towards an integrated model of bacterial conjugation. FEMS Microbiol. Rev. 39, 81-95. doi: 10.1111/1574-6976.12085

Chandler, M., de la Cruz, F., Dyda, F., Hickman, A. B., Moncalian, G., and Ton-Hoang, B. (2013). Breaking and joining single-stranded DNA: the HUH endonuclease superfamily. Nat. Rev. Microbiol. 11, 525-538. doi: 10.1038/ nrmicro3067

Chiu, C. M., Manzoor, S. E., Batt, S. M., Muntaha, S. t, Bingle, L. E. H., and Thomas, C. M. (2008). Distribution of the partitioning protein KorB on the genome of IncP-1 plasmid RK2. Plasmid 59, 163-175. doi: 10.1016/j.plasmid.2008.02.001

Chiu, C. M., and Thomas, C. M. (2004). Evidence for past integration of IncP1 plasmids into bacterial chromosomes. FEMS Microbiol. Lett. 241, 163-169. doi: 10.1016/j.femsle.2004.10.016

Davis, T. L., Helinski, D. R., and Roberts, R. C. (1992). Transcription and autoregulation of the stabilizing functions of broad-host-range plasmid RK2 in Escherichia coli, Agrobacterium tumefaciens and Pseudomonas aeruginosa. Mol. Microbiol. 6, 1981-1994. doi: 10.1111/j.1365-2958.1992.tb01371.x

de la Cruz, F., Frost, L. S., Meyer, R. J., and Zechner, E. L. (2010). Conjugative DNA metabolism in Gram-negative bacteria. FEMS Microbiol. Rev. 34, 18-40. doi: 10.1111/j.1574-6976.2009.00195.x

Dostál, L., Shao, S., and Schildbach, J. F. (2011). Tracking F plasmid TraI relaxase processing reactions provides insight into F plasmid transfer. Nucleic Acids Res. 39, 2658-2670. doi: 10.1093/nar/gkq1137

Draper, O., César, C. E., Machón, C., de la Cruz, F., and Llosa, M. (2005). Site-specific recombinase and integrase activities of a conjugative relaxase in recipient cells. Proc. Natl. Acad. Sci. U.S.A. 102, 16385-16390. doi: 10.1073/ pnas. 0506081102

Eberl, L., Givskov, M., and Schwab, H. (1992). The divergent promoters mediating transcription of the par locus of plasmid RP4 are subject to autoregulation. Mol. Microbiol. 6, 1969-1979. doi: 10.1111/j.1365-2958.1992.tb01370.x

Eberl, L., Kristensen, C. S., Givskov, M., Grohmann, E., Gerlitz, M., and Schwab, H. (1994). Analysis of the multimer resolution system encoded by the parCBA operon of broad-host-range plasmid RP4. Mol. Microbiol. 12, 131-141. doi: 10.1111/j.1365-2958.1994.tb01002.x

Figurski, D. H., Pohlman, R. F., Bechhofer, D. H., Prince, A. S., and Kelton, C. A. (1982). Broad host range plasmid RK2 encodes multiple kil genes potentially lethal to Escherichia coli host cells. Proc. Natl. Acad. Sci. U.S.A. 79, 1935-1939. doi: 10.1073/pnas.79.6.1935

Francia, M. V., Varsaki, A., Garcillán-Barcia, M. P., Latorre, A., Drainas, C., and de la Cruz, F. (2004). A classification scheme for mobilization regions of bacterial plasmids. FEMS Microbiol. Rev. 28, 79-100. doi: 10.1016/j.femsre.2003.09.001
Fürste, J. P., Pansegrau, W., Ziegelin, G., Kröger, M., and Lanka, E. (1989). Conjungative transfer of promiscuous IncP plasmids: interaction of plasmidencoded products with the transfer origin. Proc. Natl. Acad. Sci. U.S.A. 86, 1771-1775. doi: 10.1073/pnas.86.6.1771

Garcillán-Barcia, M. P., Francia, M. V., and de la Cruz, F. (2009). The diversity of conjugative relaxases and its application in plasmid classification. FEMS Microbiol. Rev. 33, 657-687. doi: 10.1111/j.1574-6976.2009.00168.x

Gerlitz, M., Hrabak, O., and Schwab, H. (1990). Partitioning of broad-hostrange plasmid RP4 is a complex system involving site-specific recombination. J. Bacteriol. 172, 6194-6203. doi: 10.1128/jb.172.11.6194-6203.1990

Gonzalez-Perez, B., Lucas, M., Cooke, L. A., Vyle, J. S., de la Cruz, F., and Moncalián, G. (2007). Analysis of DNA processing reactions in bacterial conjugation by using suicide oligonucleotides. EMBO J. 26, 3847-3857. doi: 10.1038/sj.emboj.7601806

Goryanin, I. I., Kudryavtseva, A. A., Balabanov, V. P., Biryukova, V. S., Manukhov, I. V., and Zavilgelsky, G. B. (2018). Antirestriction activities of KlcA (RP4) and ArdB (R64) proteins. FEMS Microbiol. Lett. 365:fny227. doi: 10.1093/femsle/ fny227

Greener, A., Lehman, S. M., and Helinski, D. R. (1992). Promoters of the broad host range plasmid RK2: analysis of transcription (initiation) in five species of gram-negative bacteria. Genetics 130, 27-36.

Ilangovan, A., Kay, C. W. M., Roier, S., El Mkami, H., Salvadori, E., Zechner, E. L., et al. (2017). Cryo-EM structure of a relaxase reveals the molecular basis of DNA unwinding during bacterial conjugation. Cell 169, 708-721. doi: 10.1016/j.cell. 2017.04.010

Itoh, Y., Watson, J. M., Haas, D., and Leisinger, T. (1984). Genetic and molecular characterization of the Pseudomonas plasmid pVS1. Plasmid 11, 206-220. doi: 10.1016/0147-619X(84)90027-1

Jacob, F., and Wollman, E. L. (1956). Processes of conjugation and recombination in Escherichia coli. I. Induction by conjugation or zygotic induction. Ann. Inst. Pasteur 91, 486-510.

Jagura-Burdzy, G., Kostelidou, K., Pole, J., Khare, D., Jones, A., Williams, D. R., et al. (1999a). IncC of broad-host-range plasmid RK2 modulates KorB transcriptional repressor activity in vivo and operator binding in vitro. J. Bacteriol. 181, 2807-2815. doi: 10.1128/jb.181.9.2807-2815.1999

Jagura-Burdzy, G., Macartney, D. P., Zatyka, M., Cunliffe, L., Cooke, D., Huggins, C., et al. (1999b). Repression at a distance by the global regulator KorB of promiscuous IncP plasmids. Mol. Microbiol. 32, 519-532. doi: 10.1046/j.13652958.1999.01365.x

Jagura-Burdzy, G., and Thomas, C. M. (1994). KorA protein of promiscuous plasmid RK2 controls a transcriptional switch between divergent operons for plasmid replication and conjugative transfer. Proc. Natl. Acad. Sci. U.S.A. 91, 10571-10575. doi: 10.1073/pnas.91.22.10571

Jagura-Burdzy, G., and Thomas, C. M. (1995). Purification of KorA protein from broad host range plasmid RK2: definition of a hierarchy of KorA operators. J. Mol. Biol. 253, 39-50. doi: 10.1006/jmbi.1995.0534

Jagura-Burdzy, G., and Thomas, C. M. (1997). Dissection of the switch between genes for replication and transfer of promiscuous plasmid RK2: basis of the dominance of $\operatorname{trfAp}$ over $\operatorname{trbAp}$ and specificity for KorA in controlling the switch. J. Mol. Biol. 265, 507-518. doi: 10.1006/jmbi.1996. 0747

Jones, A. L., Barth, P. T., and Wilkins, B. M. (1992). Zygotic induction of plasmid $s s b$ and $p s i B$ genes following conjugative transfer of Incl1 plasmid Collb-P9. Mol. Microbiol. 6, 605-613. doi: 10.1111/j.1365-2958.1992.tb01507.x

Jovanovic, O. S., Ayres, E. K., and Figurski, D. H. (1992). The replication initiator operon of promiscuous plasmid RK2 encodes a gene that complements an Escherichia coli mutant defective in single-stranded DNA-binding protein. J. Bacteriol. 174, 4842-4846. doi: 10.1128/jb.174.14.4842-4846.1992

Jovanovic, O. S., Ayres, E. K., and Figurski, D. H. (1994). Host-inhibitory functions encoded by promiscuous plasmids. Transient arrest of Escherichia coli segregants that fail to inherit plasmid RK2. J. Mol. Biol. 237, 52-64. doi: 10.1006/jmbi.1994.1208

Kingsman, A., and Willetts, N. (1978). The requirements for conjugal DNA synthesis in the donor strain during Flac transfer. J. Mol. Biol. 122, 287-300. doi: 10.1016/0022-2836(78)90191-2

Kornacki, J. A., Burlage, R. S., and Figurski, D. H. (1990). The kil-kor regulon of broad-host-range plasmid RK2: nucleotide sequence, polypeptide product, and expression of regulatory gene korC. J. Bacteriol. 172, 3040-3050. doi: 10.1128/ jb.172.6.3040-3050.1990 
Kornacki, J. A., Chang, C. H., and Figurski, D. H. (1993). Kil-kor regulon of promiscuous plasmid RK2: structure, products, and regulation of two operons that constitute the kilE locus. J. Bacteriol. 175, 5078-5090. doi: 10.1128/jb.175. 16.5078-5090.1993

Kostelidou, K., Jones, A. C., and Thomas, C. M. (1999). Conserved C-terminal region of global repressor KorA of broad-host-range plasmid RK2 is required for co-operativity between KorA and a second RK2 global regulator, KorB. J. Mol. Biol. 289, 211-221. doi: 10.1006/jmbi.1999.2761

Kostelidou, K., and Thomas, C. M. (2000). The hierarchy of KorB binding at its 12 binding sites on the broad-host-range plasmid RK2 and modulation of this binding by IncC1 protein. J. Mol. Biol. 295, 411-422. doi: 10.1006/jmbi.1999. 3359

Kostelidou, K., and Thomas, C. M. (2002). DNA recognition by the KorA proteins of IncP-1 plasmids RK2 and R751. Biochim. Biophys. Acta 1576, 110-118. doi: 10.1016/S0167-4781(02)00306-8

Lanka, E., and Wilkins, B. M. (1995). DNA processing reactions in bacterial conjugation. Annu. Rev. Biochem. 64, 141-169. doi: 10.1146/annurev.bi.64. 070195.001041

Lawley, T., Wilkins, B., and Frost, L. (2004). "Conjugation in Gram-negative bacteria," in Plasmid Biology, eds G. Phillips and B. Funnell (Washington, DC: ASM Press), 203-226. doi: 10.1128/9781555817732

Llosa, M., Gomis-Rüth, F. X., Coll, M., and de la Cruz, F. (2002). Bacterial conjugation: a two-step mechanism for DNA transport. Mol. Microbiol. 45, 1-8. doi: 10.1046/j.1365-2958.2002.03014.x

Masai, H., and Arai, K. I. (1997). Frpo: a novel single-stranded DNA promoter for transcription and for primer RNA synthesis of DNA replication. Cell 89, 897-907. doi: 10.1016/S0092-8674(00)80275-5

Miyakoshi, M., Nishida, H., Shintani, M., Yamane, H., and Nojiri, H. (2009). Highresolution mapping of plasmid transcriptomes in different host bacteria. BMC Genomics 10:12. doi: 10.1186/1471-2164-10-12

Miyakoshi, M., Shintani, M., Inoue, K., Terabayashi, T., Sai, F., Ohkuma, M., et al. (2012). ParI, an orphan ParA family protein from Pseudomonas putida KT2440specific genomic island, interferes with the partition system of IncP-7 plasmids. Environ. Microbiol. 14, 2946-2959. doi: 10.1111/j.1462-2920.2012.02861.x

Miyakoshi, M., Shintani, M., Terabayashi, T., Kai, S., Yamane, H., and Nojiri, H. (2007). Transcriptome analysis of Pseudomonas putida KT2440 harboring the completely sequenced IncP-7 plasmid pCAR1. J. Bacteriol. 189, 6849-6860. doi: 10.1128/JB.00684-07

Motallebi-Veshareh, M., Rouch, D. A., and Thomas, C. M. (1990). A family of ATPases involved in active partitioning of diverse bacterial plasmids. Mol. Microbiol. 4, 1455-1463. doi: 10.1111/j.1365-2958.1990.tb02056.x

Nasim, M. T., Eperon, I. C., Wilkins, B. M., and Brammar, W. J. (2004). The activity of a single-stranded promoter of plasmid Collb-P9 depends on its secondary structure. Mol. Microbiol. 53, 405-417. doi: 10.1111/j.1365-2958.2004.04114.x

Nojiri, H. (2013). Impact of catabolic plasmids on host cell physiology. Curr. Opin. Biotechnol. 24, 423-430. doi: 10.1016/j.copbio.2012.09.014

Pansegrau, W., Balzer, D., Kruft, V., Lurz, R., and Lanka, E. (1990a). In vitro assembly of relaxosomes at the transfer origin of plasmid RP4. Proc. Natl. Acad. Sci. U.S.A. 87, 6555-6559. doi: 10.1073/pnas.87.17.6555

Pansegrau, W., and Lanka, E. (1996). Mechanisms of initiation and termination reactions in conjugative DNA processing: independence of tight substrate binding and catalytic activity of relaxase (TraI) of IncP $\alpha$ plasmid RP4. J. Biol. Chem. 271, 13068-13076. doi: 10.1074/jbc.271.22.13068

Pansegrau, W., Lanka, E., Barth, P. T., Figurski, D. H., Guiney, D. G., Haas, D., et al. (1994a). Complete nucleotide sequence of Birmingham IncP $\alpha$ plasmids. Compilation and comparative analysis. J. Mol. Biol. 239, 623-663. doi: 10.1006/ jmbi.1994.1404

Pansegrau, W., Schröder, W., and Lanka, E. (1994b). Concerted action of three distinct domains in the DNA cleaving-joining reaction catalyzed by relaxase (TraI) of conjugative plasmid RP4. J. Biol. Chem. 269, 2782-2789.

Pansegrau, W., Schröder, W., and Lanka, E. (1993). Relaxase (TraI) of IncP $\alpha$ plasmid RP4 catalyzes a site-specific cleaving- joining reaction of singlestranded DNA. Proc. Natl. Acad. Sci. U.S.A. 90, 2925-2929. doi: 10.1073/pnas. 90.7.2925

Pansegrau, W., Ziegelin, G., and Lanka, E. (1990b). Covalent association of the traI gene product of plasmid RP4 with the $5^{\prime}$-terminal nucleotide at the relaxation nick site. J. Biol. Chem. 265, 10637-10644.

Rees, C. E. D., and Wilkins, B. M. (1990). Protein transfer into the recipient cell during bacterial conjugation: studies with F and RP4. Mol. Microbiol. 4, 1199-1205. doi: 10.1111/j.1365-2958.1990.tb00695.x
Roberts, R. C., and Helinski, D. R. (1992). Definition of a minimal plasmid stabilization system from the broad-host-range plasmid RK2. J. Bacteriol. 174, 8119-8132. doi: 10.1128/jb.174.24.8119-8132.1992

Roberts, R. C., Ström, A. R., and Helinski, D. R. (1994). The parDE operon of the broad-host-range plasmid RK2 specifies growth inhibition associated with plasmid loss. J. Mol. Biol. 237, 35-51. doi: 10.1006/jmbi.1994.1207

Rosche, T. M., Siddique, A., Larsen, M. H., and Figurski, D. H. (2000). Incompatibility protein IncC and global regulator KorB interact in active partition of promiscuous plasmid RK2. J. Bacteriol. 182, 6014-6026. doi: 10. 1128/JB.182.21.6014-6026.2000

Schröder, G., Krause, S., Zechner, E. L., Traxler, B., Yeo, H. J., Lurz, R., et al. (2002). TraG-like proteins of DNA transfer systems and of the Helicobacter pylori type IV secretion system: inner membrane gate for exported substrates? J. Bacteriol. 184, 2767-2779. doi: 10.1128/JB.184.10.2767-2779.2002

Schröder, G., and Lanka, E. (2003). TraG-like proteins of type IV secretion systems: functional dissection of the multiple activities of TraG (RP4) and TrwB (R388). J. Bacteriol. 185, 4371-4381. doi: 10.1128/JB.185.15.4371-4381.2003

Shintani, M., Takahashi, Y., Tokumaru, H., Kadota, K., Hara, H., Miyakoshi, M., et al. (2010). Response of the Pseudomonas host chromosomal transcriptome to carriage of the IncP-7 plasmid pCAR1. Environ. Microbiol. 12, 1413-1426. doi: 10.1111/j.1462-2920.2009.02110.x

Shintani, M., Tokumaru, H., Takahashi, Y., Miyakoshi, M., Yamane, H., Nishida, H., et al. (2011). Alterations of RNA maps of IncP-7 plasmid pCAR1 in various Pseudomonas bacteria. Plasmid 66, 85-92. doi: 10.1016/j.plasmid.2011. 06.001

Sia, E. A., Roberts, R. C., Easter, C., Helinski, D. R., and Figurski, D. H. (1995). Different relative importances of the par operons and the effect of conjugal transfer on the maintenance of intact promiscuous plasmid RK2. J. Bacteriol. 177, 2789-2797. doi: 10.1128/jb.177.10.2789-2797.1995

Thomas, C. M. (2000). Paradigms of plasmid organization. Mol. Microbiol. 37, 485-491. doi: 10.1046/j.1365-2958.2000.02006.x

Thomas, C. M. (2006). Transcription regulatory circuits in bacterial plasmids. Biochem. Soc. Trans. 34, 1072-1074. doi: 10.1042/BST0341072

Thomas, C. M., Ibbotson, J. P., Wang, N., Smith, C. A., Tipping, R., and Loader, N. M. (1988). Gene regulation on broad host range plasmid RK2: identification of three novel operons whose transcription is repressed by both KorA and KorC. Nucleic Acids Res. 12, 5345-5359. doi: 10.1093/nar/16.12.5345

Thomas, C. M., and Nielsen, K. M. (2005). Mechanisms of, and barriers to, horizontal gene transfer between bacteria. Nat. Rev. Microbiol. 3, 711-721. doi: 10.1038/nrmicro1234

Thorsted, P. B., Shah, D. S., Macartney, D., Kostelidou, K., and Thomas, C. M. (1996). Conservation of the genetic switch between replication and transfer genes of IncP plasmids but divergence of the replication functions which are major host-range determinants. Plasmid 36, 95-111. doi: 10.1006/plas.1996. 0037

Vial, L., and Hommais, F. (2020). Plasmid-chromosome cross-talks. Environ. Microbiol. 22, 540-556. doi: 10.1111/1462-2920.14880

Waksman, G. (2019). From conjugation to T4S systems in Gram-negative bacteria: a mechanistic biology perspective. EMBO Rep. 20:e47012. doi: 10.15252/embr. 201847012

Waters, V. L., and Guiney, D. G. (1993). Processes at the nick region link conjugation, T-DNA transfer and rolling circle replication. Mol. Microbiol. 9, 1123-1130. doi: 10.1111/j.1365-2958.1993.tb01242.x

Wilkins, B. M., and Hollom, S. E. (1974). Conjugational synthesis of F lact and Col I DNA in the presence of rifampicin and in Escherichia coli K12 mutants defective in DNA synthesis. Mol. Gen. Genet. 134, 143-156. doi: 10.1007/ BF00268416

Willetts, N., and Wilkins, B. (1984). Processing of plasmid DNA during bacterial conjugation. Microbiol. Rev. 48, 24-41. doi: 10.1128/mmbr.48.1.24-41.1984

Wilson, J. W., Sia, E. A., and Figurski, D. H. (1997). The kilE locus of promiscuous IncP $\alpha$ plasmid RK2 is required for stable maintenance in Pseudomonas aeruginosa. J. Bacteriol. 179, 2339-2347. doi: 10.1128/jb.179.7.2339-2347. 1997

Zatyka, M., Bingle, L., Jones, A. C., and Thomas, C. M. (2001). Cooperativity between KorB and TrbA repressors of broad-host-range plasmid RK2. J. Bacteriol. 183, 1022-1031. doi: 10.1128/JB.183.3.1022-1031.2001

Zatyka, M., Jagura-Burdzy, G., and Thomas, C. M. (1994). Regulation of transfer genes of promiscuous IncP $\alpha$ plasmid RK2: repression of Tral region transcription both by relaxosome proteins and by the Tra2 regulator TrbA. Microbiology 140, 2981-2990. doi: 10.1099/13500872-140-11-2981 
Zatyka, M., Jagura-Burdzy, G., and Thomas, C. M. (1997). Transcriptional and translational control of the genes for the mating pair formation apparatus of promiscuous IncP plasmids. J. Bacteriol. 179, 7201-7209. doi: 10.1128/jb.179. 23.7201-7209.1997

Ziegelin, G., Fürste, J. P., and Lanka, E. (1989). TraJ protein of plasmid RP4 binds to a 19-base pair invert sequence repetition within the transfer origin. J. Biol. Chem. 264, 11989-11994.

Ziegelin, G., Pansegrau, W., Lurz, R., and Lanka, E. (1992). TraK protein of conjugative plasmid RP4 forms a specialized nucleoprotein complex with the transfer origin. J. Biol. Chem. 267, 17279-17286.
Conflict of Interest: The authors declare that the research was conducted in the absence of any commercial or financial relationships that could be construed as a potential conflict of interest.

Copyright (c) 2020 Miyakoshi, Ohtsubo, Nagata and Tsuda. This is an open-access article distributed under the terms of the Creative Commons Attribution License (CC BY). The use, distribution or reproduction in other forums is permitted, provided the original author(s) and the copyright owner(s) are credited and that the original publication in this journal is cited, in accordance with accepted academic practice. No use, distribution or reproduction is permitted which does not comply with these terms. 